\title{
GEOCHEMICAL MODELING OF ABANDONED SULFIDIC FLOTATION MILL TAILINGS: THE CASE OF KIRKI, NE GREECE
}

\section{Triantafyllidis S.}

National Technical University of Athens, School of Mining and Metallurgical Engineering, 157 80, Zografou, Athens, Greece, striantafyllidis@metal.ntua.gr

\begin{abstract}
The Kirki flotation plant is located approximately $5 \mathrm{~km}$ south of the Agios Filippos open pit mine (Thrace, NE Greece), and unconfined mill tailings are exposed to atmospheric conditions. Rain water accumulates on the surface of the tailings and interacts with the solids, resulting in highly acidic and oxidative surface solutions with increased heavy metal content. The tailings material is dominated by gangue minerals with very low acid buffering capacity, including quartz, kaolinite/dickite, pyrophyllite and minor orthoclase. Secondary phases identified include mainly species of the jarosite group, gypsum and anglesite. No primary ore minerals besides pyrite are identified. The finegrained character of the tailings material favors fast reactions between the surface waters and the solids. The speciation/mass transfer computer code PHREEQC-2 and the MINTEQ database were employed for geochemical modeling of the acidic surface waters of the tailings dams T1 and T2. Three different scenarios were employed, "Direct Precipitation", "Mixing with Rainwater" and "Evaporation" to check the equilibrium between the developed surface solutions and the secondary minerals identified in the tailings. The purpose of this work is to understand the way heavy metals may be locked to the lattice of secondary minerals, or dispersed/dissolved after dissolution of unstable secondary phases.
\end{abstract}

Keywords: Acidic surface waters, secondary minerals, geochemical modelling.

\section{Пєрí $\eta \psi \eta$}

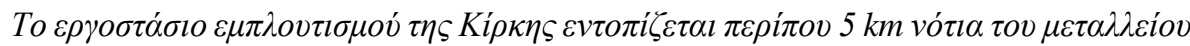

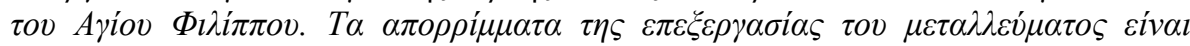

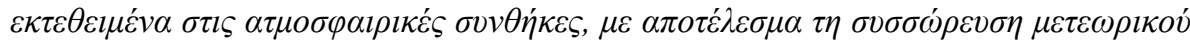

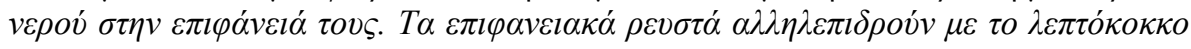

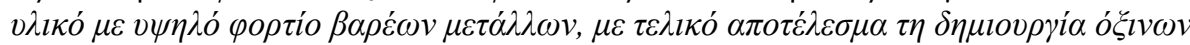

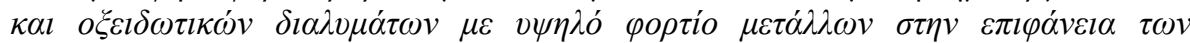

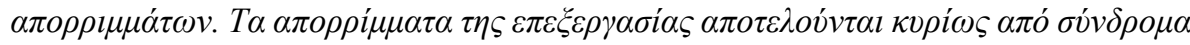

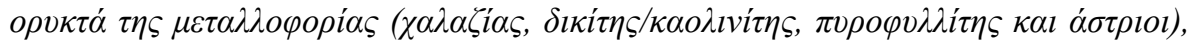

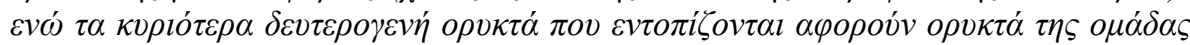

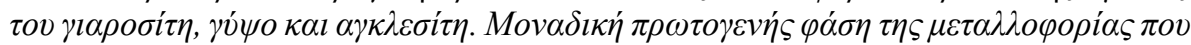

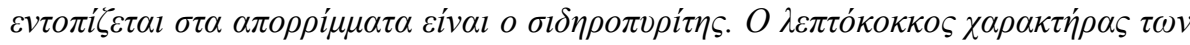

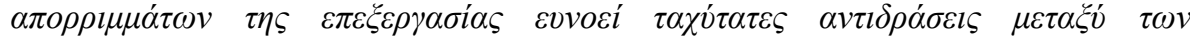

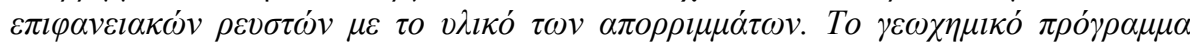

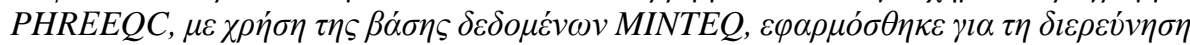

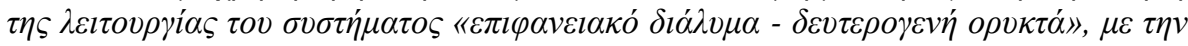




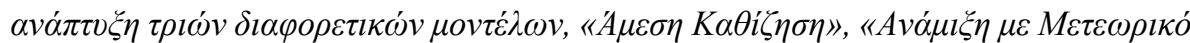

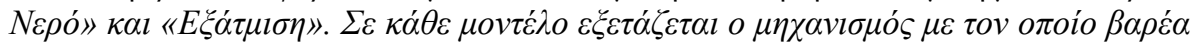

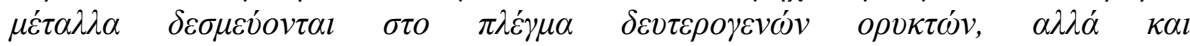

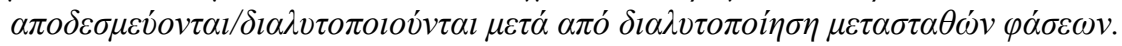

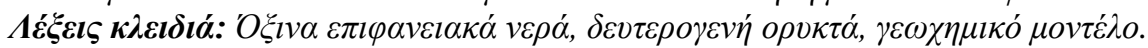

\section{Introduction}

A major issue the mining industry faces is the safe disposal of ore processing waste or tailings. Tailings are defined as the processing waste from a mill, washery or concentrator where the economic metals or minerals from the mined resource are removed (Lottermoser, 2010). During the early years of ore exploitation, the produced processing wastes were usually dumped in nearby streams or creeks without consideration of their environmental impact (Plumlee and Logsdon, 1999). In recent years and following processing, the tailings are usually disposed as slurry or paste to certain facilities and present unique environmental and physical characteristics. Mill tailings originating form sulfide ores present challenges namely because of the high oxidation potential of sulfides remaining in the tailings (Fergusson, 1990; Larsen et al., 2001; Lacal et al., 2003) and possible generation of Acid Rock Drainage (ARD). The flow of meteoric water over sulfidic tailings may further increase the potential for metal leaching from tailings due to the fine to very fine-grained character of the tailings material (Mohamed et al., 2002) but also due to dissolution of heavy-metal bearing secondary phases that develop at the surface and near the surface of the tailings (Wray, 1998). Therefore, abandoned mine waste disposal sites containing sulfide minerals may pose significant environmental threats and may severely contaminate surface and groundwater as well as soils and ecosystems (Bigham and Nordstrom, 2000; Draves and Fox, 1998; Groudev et al. 1999; Hudson-Edwards et al., 2003; Komnitsas et al. 1998; Adam, 2003).

\section{Site description}

The Kirki (Agios Filippos) high sulfidation deposit is hosted into the Eocene-Oligocene rock sequences of SE Evros county and is associated with orogenic calc-alkaline to high-potassium calcalkaline magmatism. The epithermal mineralization is developed between two sub-parallel fault zones that form the western and the eastern part of the open pit. An advanced argillic alteration with alunite and pyrophyllite followed an early pervasive grey silicification of the rocks. The base metal sector has been exposed due to erosion of the upper part of the epithermal system (Skarpelis, 1999). The mineralization is characterized by complex mineralogy with several $\mathrm{Pb}$-bearing and $\mathrm{Pb}-\mathrm{As}-$ bearing sulfosalts (Moelo et al., 1985; Moelo et al., 1990).

The Kirki flotation plant and tailings ponds, built approximately $5 \mathrm{~km}$ south of the Agios Filippos mine (Fig. 1), are founded on Tertiary clastic sediments, including mainly breccio-conglomerates, sandstones, shales and marls (Michael and Dimadis, 2006). The flotation plant comprises eight tailings ponds in total (4 of them depicted in Fig.1) built in favorable locations that required minimum earthworks, while no measures to protect the environment were taken (Directives 2006/21/EC and 98/83/EC) (Triantafyllidis et al., 2007). Sandstones, conglomerates and finegrained tailings were used for the construction of the tailing dump walls with questionable results regarding their stability, as evident by the collapse of the walls at dumps T2, T3 and T4 (Triantafyllidis, 2006). Additionally, the dumps were constructed without consideration of a drainage system thus favoring accumulation of rain water on their surface (Loupasakis and Konstantopoulou, 2010). 


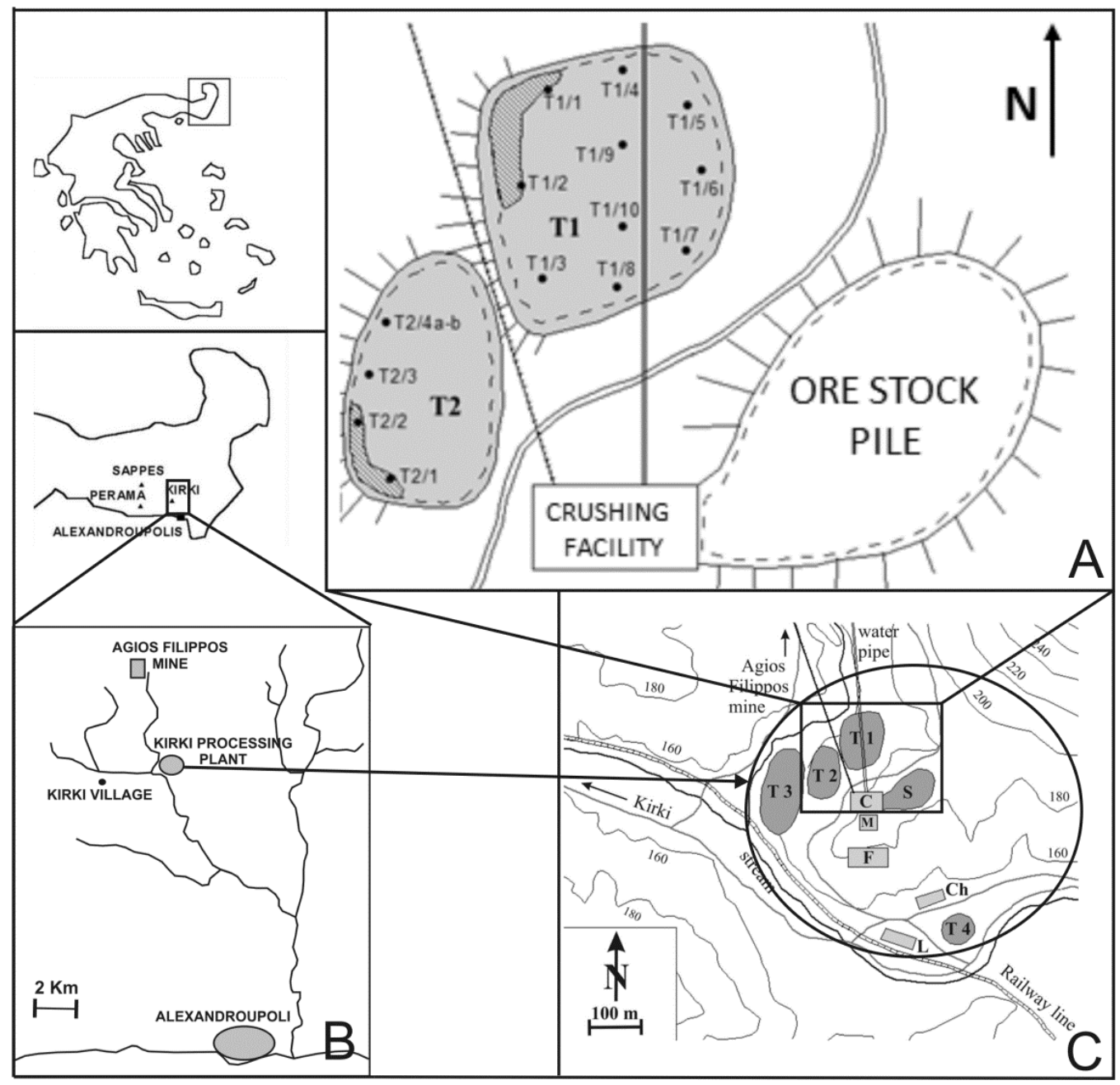

Figure 1 - Location map of the Kirki processing plant. A. Sampling points for tailings dams T1 and T2. Small water ponds formed on the surface of the dams appear with dashed lines.

\section{Kirki flotation plant.}

\section{Sampling - Analytical methods}

Water samples were collected from the surface of tailings dams T1 and T2 (Fig.1A) in September 2001 and June 2003, applying standard sampling techniques. Temperature, pH and Eh were measured on site using a WTW pH 320/Set-2 electronic pH-meter. Water samples were filtered through a $0.45 \mu \mathrm{m}$ Millipore filter and acidified with $1 \mathrm{M} \mathrm{HNO}_{3}$ for cation analyses. Concentrations of $\mathrm{Pb}, \mathrm{Cu}, \mathrm{Zn}, \mathrm{Fe}, \mathrm{Cd}, \mathrm{Ni}, \mathrm{Co}, \mathrm{As}, \mathrm{Hg}, \mathrm{Mn}$ and $\mathrm{Sb}$ were measured commercially with an inductively coupled plasma atomic emission spectrometer (ICP-AES), whereas $\mathrm{SO}_{4}$ concentrations using a Hach DR 2000 spectrophotometer. Bulk samples from successive tailings layers were collected up to a depth of $1.6 \mathrm{~m}$ (Fig.1A). Samples were dried at room temperature, and sieved to achieve collection of the finer-grained material for more reliable identification of the secondary phases with X-RAY diffraction. The samples were then pulverized, homogenized and split in two so that analyses were done in duplicate. Mineral identification was carried out at the Laboratory of Economic Geology and Geochemistry, University of Athens by X-ray Diffractometry and Scanning Electron Microscopy (SEM). X-ray diffractometry included the use of a SIEMENS D5005 X-ray 
Diffractometer with $\mathrm{Cu}(\mathrm{k} \alpha)$ radiation at $40 \mathrm{kV} / 20 \mathrm{~mA}$ operating conditions. Scanning Electron Microscopy involved the use of a Jeol JSM 5600 scanning electron microscope combined with energy dispersive X-ray spectrometry (EDS) (OXFORD ISIS Link electron microprobe) and equipped with a Jeol Analytical back scattered electron detector. Operating conditions for the SEM were $20 \mathrm{kV}$ accelerating voltage and $0.5 \mathrm{nA}$ beam current. Counting time for each analysis was 50 sec, with $15 \mathrm{sec}$ dead time.

\section{Analytical data used}

The geochemical characteristics of surface waters accumulated on the surface of tailings dams T1 and $\mathrm{T} 2$ are given in table 1 . In table 2 selected major and trace elements analyses are given for tailings dams T1 and T2, whereas the secondary phases identified by X-ray Diffraction and Scanning Electron Microscopy are presented in table 3.

Table 1 - Physicochemical characteristics of stagnant surface waters on tailings dams T1 and T2, after Triantafyllidis (2006) (dissolved ions in $\mathrm{mg} / \mathrm{L}$, Eh in $\mathrm{mV}$ ).

\begin{tabular}{|l|c|c|c|c|c|c|c|}
\hline & pH & Eh & SO$_{4}$ & As & Cd & Co & Cu \\
\hline Tailings dam T1 \\
\hline Min & 3.1 & 160 & 2600 & b.d.l. & 1.9 & 0.12 & 1.0 \\
\hline Max & 4.4 & 256 & 6300 & 0.12 & 14.7 & 1.10 & 18.0 \\
\hline Mean & 3.7 & 239 & 4450 & - & 8.3 & 0.56 & 8.1 \\
\hline Stand. Dev. & 0.6 & 37 & 1752 & - & 5.5 & 0.45 & 7.5 \\
\hline \multicolumn{7}{|c|}{ Tailings dam T2 } \\
\hline Min & 3.0 & 226 & 2450 & b.d.l. & 3.8 & 0.25 & 5.0 \\
\hline Max & 3.4 & 235 & 17500 & 0.33 & 35.3 & 2.90 & 11.6 \\
\hline Mean & 3.3 & 229 & 9975 & - & 19.6 & 1.61 & 8.3 \\
\hline Stand. Dev. & 0.1 & 4 & 7261 & - & 15.5 & 1.25 & 3.0 \\
\hline
\end{tabular}

Table 1 continued

\begin{tabular}{|l|c|c|c|c|c|c|}
\hline & Fe & Mn & Ni & Pb & Zn & Sb \\
\hline \multicolumn{7}{|c|}{ Tailings dam T1 } \\
\hline Min & 0.1 & 121 & 0.9 & 1.0 & 193 & b.d.l. \\
\hline Max & 130 & 613 & 5.2 & 3.7 & 1398 & b.d.l. \\
\hline Mean & 64.6 & 385 & 3.1 & 2.4 & 798 & - \\
\hline Stand. Dev. & 64.1 & 230 & 2.1 & 1.2 & 575 & - \\
\hline \multicolumn{7}{|c|}{ Tailings dam T2 } \\
\hline Min & 1.0 & 188 & 1.6 & 2.8 & 278 & b.d.l. \\
\hline Max & 4.8 & 2852 & 17.5 & 4.8 & 4298 & 0.15 \\
\hline Mean & 2.7 & 1518 & 8.8 & 3.4 & 2223 & - \\
\hline Stand. Dev. & 1.3 & 1166 & 7.3 & 0.7 & 1955 & - \\
\hline b.d.1.: below detection limit \\
As<0.01 mg/lt \\
Sb<0.002 mg/lt \\
Hg<0.001 mg/lt (Hydride/cold vapor technique) \\
Ag<0.002 mg/lt
\end{tabular}


Table 2 - Selected major and trace elements analyses of tailings dam material in wt \% and ppm respectively, after Triantafyllidis (2006).

\begin{tabular}{|l|c|c|c|c|c|c|c|c|}
\hline & $\mathbf{S i O}_{2}$ & $\mathbf{A l}_{2} \mathbf{O}_{3}$ & $\mathbf{C a O}$ & $\mathbf{N a}_{2} \mathbf{O}$ & $\mathbf{F e}_{2} \mathbf{O}_{3}$ & $\mathbf{K}_{2} \mathbf{O}$ & $\mathbf{T i O}_{2}$ & L.O.I. \\
\hline Min & 63,0 & 9.12 & 0.27 & 0.09 & 2.77 & 0.74 & 0.44 & 5.6 \\
\hline Max & 84.1 & 20.95 & 0.54 & 0.31 & 3.61 & 1.82 & 0.49 & 10.9 \\
\hline Mean & 73.9 & 14.5 & 0.43 & 0.15 & 3.1 & 0.84 & 0.46 & 7.7 \\
\hline Stand. Dev. & 8.5 & 5.0 & 0.11 & 0.07 & 0.3 & 0.39 & 0.02 & 2.2 \\
\hline & $\mathbf{P b}$ & $\mathbf{Z n}$ & $\mathbf{C u}$ & $\mathbf{C d}$ & $\mathbf{A s}$ & $\mathbf{M n}$ & $\mathbf{B i}$ & Sb \\
\hline Min & 2597 & 2082 & 57 & 14 & 92 & 200 & 38 & 13 \\
\hline Max & 13991 & 11013 & 526 & 122 & 238 & 6828 & 339 & 60 \\
\hline Mean & 4465 & 6086 & 109 & 45 & 127 & 1545 & 60 & 16.5 \\
\hline Stand. Dev. & 3818 & 3285 & 149.6 & 38.8 & 46.8 & 2002 & 101 & 15.8 \\
\hline L.O.I. Loss on Ignition
\end{tabular}

Table 3 - Secondary phases identified in the tailings material of dumps T1 and T2.

\begin{tabular}{|c|c|c|c|}
\hline Mineral phase & Empirical Formula & $\begin{array}{c}\text { Tailing dump } \\
\text { T1 }\end{array}$ & $\begin{array}{c}\text { Tailing dump } \\
\text { T2 }\end{array}$ \\
\hline Jarosite group* & $\left(\mathrm{K}, \mathrm{Na}, \mathrm{Pb}, \mathrm{H}_{3} \mathrm{O}\right) \mathrm{Fe}^{+3}{ }_{3}\left(\mathrm{SO}_{4}\right)_{2}(\mathrm{OH})_{6}$ & +++++ & +++++ \\
\hline Gypsum & $\mathrm{CaSO}_{4} \times 2 \mathrm{H}_{2} \mathrm{O}$ & +++++ & +++++ \\
\hline Anglesite & $\mathrm{PbSO}_{4}$ & +++ & + \\
\hline Butlerite & $\mathrm{Fe}^{+3}\left(\mathrm{SO}_{4}\right)(\mathrm{OH}) \times 2 \mathrm{H}_{2} \mathrm{O}$ & + & + \\
\hline Ktenasite & $\mathrm{Zn}(\mathrm{Cu}, \mathrm{Zn})_{4}\left(\mathrm{SO}_{4}\right)_{2}(\mathrm{OH})_{6} \times 6 \mathrm{H}_{2} \mathrm{O}$ & & + \\
\hline Giniite & $\mathrm{Fe}^{2+} \mathrm{Fe}^{3+}{ }_{4}\left(\mathrm{PO}_{4}\right)_{4}(\mathrm{OH})_{2} \times 2\left(\mathrm{H}_{2} \mathrm{O}\right)$ & + & \\
\hline Zykaite & $\mathrm{Fe}^{3+}{ }_{4}\left(\mathrm{AsO}_{4}\right)_{3}\left(\mathrm{SO}_{4}\right)(\mathrm{OH}) \times 15\left(\mathrm{H}_{2} \mathrm{O}\right)$ & + & \\
\hline Osarizawaite & $\mathrm{PbCuAl}_{2}\left(\mathrm{SO}_{4}\right)_{2}(\mathrm{OH})_{6}$ & + & \\
\hline
\end{tabular}

\section{Application of PHREEQC geochemical code}

The correlation between the chemistry of the surface waters on tailing dumps T1 and T2 (examined separately) and the mineralogy and geochemistry of the tailings material from each dam was investigated with the use of the geochemical code PHREEQC-V2 (Parkhurst and Appelo, 1999). Thermodynamic data was taken from MINTEQ database (Allison et al., 1991). Saturation Indices were calculated only for jarosite group species, anglesite and gypsum, since thermodynamic data for ktenasite, butlerite, giniite, zykaite and osarizawaite are not included in the MINTEQ database. Imported parameters in the system (Table 4) include: Eh (as pe), pH, $\mathrm{As}, \mathrm{Ag}, \mathrm{Cd}, \mathrm{Cu}, \mathrm{Fe}$ (total), $\mathrm{K}$, $\mathrm{Na}, \mathrm{Ni}, \mathrm{Mn}, \mathrm{Pb}, \mathrm{Sb}, \mathrm{Zn}, \mathrm{Cu}$ and $\mathrm{SO}_{4}{ }^{-2}$. The dissolved concentrations for $\mathrm{Ca}, \mathrm{Na}, \mathrm{K}$ for the PHREEQC models were based on estimate after geochemical analyses performed on acid mine drainage samples from the Agios Filippos mine (Liakopoulos, 2009). The pe (Eh) values employed in the PHREEQC tests are changed relative to those measured during sampling. At a center point surface stagnant waters are not equilibrated with atmosphere, thus preserving significantly higher pe conditions than normal measured values (Heikkinen et al., 2009). As stated by Manchester et al. (2008), near the surface of sulfide tailings disposal facilities pe values may be high and approach the theoretical maximum of 13.75 for $\mathrm{O}_{2}$ at $\mathrm{pH}=7$. Several different scenarios were employed for the system "tailings surface waters - tailings secondary mineralogy" (Fig. 2), including:

- "Direct Precipitation"

- "Mixing with Rainwater"

- "Evaporation". 
Table 4 - Physicochemical characteristics of solutions applied for PHREEQC modelling.

\begin{tabular}{|c|c|c|c|}
\hline $\begin{array}{l}\text { Parameter } \\
\text { added to the } \\
\text { program }\end{array}$ & $\begin{array}{c}\text { Meteoric water* (applied } \\
\text { on model "Mixing with } \\
\text { Rainwater") }\end{array}$ & $\begin{array}{c}\text { Tailings dam } \\
\text { T1 surface } \\
\text { water }\end{array}$ & $\begin{array}{c}\text { Tailings dam } \\
\text { T2 surface } \\
\text { water }\end{array}$ \\
\hline Temperature & 25 & 28.2 & 29.4 \\
\hline pH & 5.5 & 3.7 & 3.3 \\
\hline Eh & 4 & 6 & 9 \\
\hline Density & 1 & 1 & 1 \\
\hline $\mathbf{C a}$ & 0.2 & 100 & 100 \\
\hline $\mathbf{K}$ & 0.35 & 10 & 10 \\
\hline $\mathbf{N a}$ & 0.6 & 20 & 20 \\
\hline $\mathrm{SO}_{4}$ & 0.18 & 4450 & 9975 \\
\hline Ag & & 0.002 & 0.002 \\
\hline As & & 0.063 & 0.168 \\
\hline Cd & & 8.3 & 19.6 \\
\hline Co & & 0.6 & 1.6 \\
\hline $\mathbf{C u}$ & & 8 & 8.3 \\
\hline $\mathbf{F e}$ & & 65 & 2.7 \\
\hline $\mathbf{H g}$ & & 0.005 & 0.005 \\
\hline Mn & & 385 & 1520 \\
\hline $\mathrm{Ni}$ & & 3.1 & 8.8 \\
\hline $\mathbf{P b}$ & & 2.4 & 3.4 \\
\hline $\mathbf{S b}$ & & 0.02 & 0.08 \\
\hline $\mathbf{Z n}$ & & 798 & 2212 \\
\hline $\begin{array}{l}\text { * After Carroll } \\
\text { Temperature in } \\
\text { Density in gr/cr } \\
\text { Eh in pe } \\
\text { All ions in } \mathrm{mg} /\end{array}$ & $\begin{array}{l}962) \\
C\end{array}$ & & \\
\hline
\end{tabular}
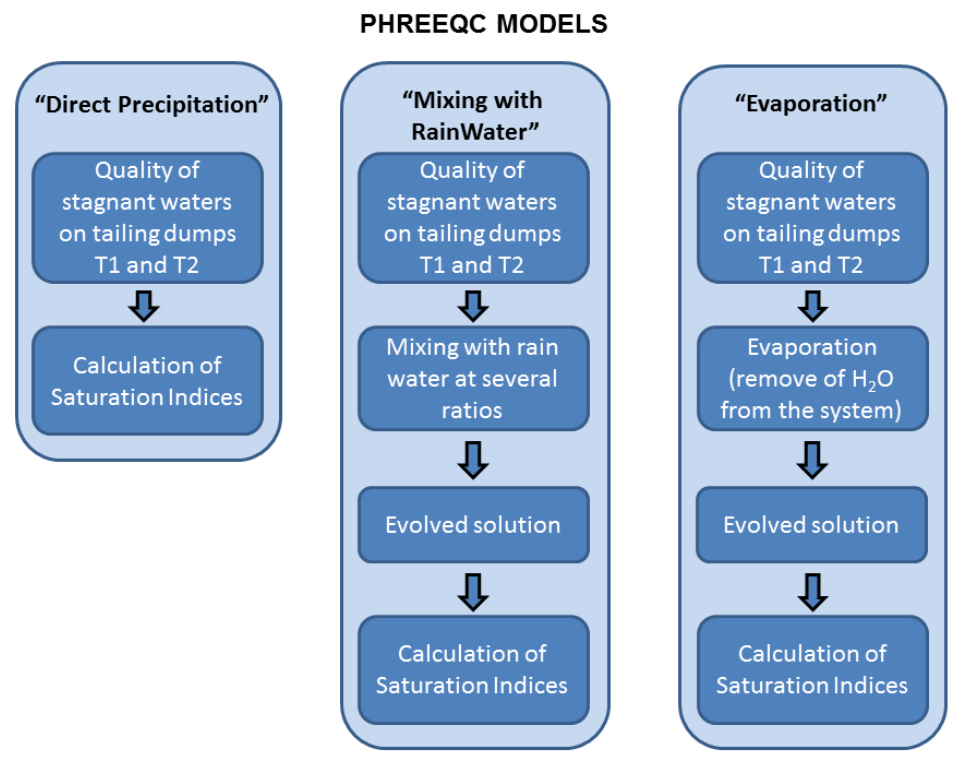

Figure 2 - Schematic representation of PHREEQC models applied in the study. 


\section{Results of PHREEQC tests}

\subsection{Direct precipitation}

The first model (Direct Precipitation) examines the equilibrium between the stagnant surface waters on the tailing ponds and the secondary phases identified in the tailings material, and calculates the Saturation Indices (SI) of specific phases based on the MINTEQ database (Fig. 2, Table 5). This model showed that anglesite is saturated and slightly undersaturated for dams T2 and T1 respectively, whereas only in dam T2 K-jarosite precipitates $(\mathrm{SI}>0)$. All other secondary phases identified by XRD and SEM are undersaturated $(\mathrm{SI}<0)$.

Table 5 - Calculated Saturation Indices for model "Direct Precipitation" for tailings dams

T1 and T2.

\begin{tabular}{|l|c|c|}
\hline Mineral phase & Tailings dump T1 & Tailings dump T2 \\
\hline Anglesite & -0.11 & $\mathbf{0 . 0 3}$ \\
\hline H-jarosite & -4.43 & -1.61 \\
\hline Na-jarosite & -4.96 & -2.66 \\
\hline K-Jarosite & -1.95 & $\mathbf{0 . 3 2}$ \\
\hline Gypsum & -0.60 & -0.57 \\
\hline
\end{tabular}

\subsection{Mixing with rainwater}

The second model (Mixing with Rainwater) examines mixing of the surface stagnant waters with rain water (geochemical data for rain water were taken from Carroll, 1962) at several ratios, and checks the equilibrium between the solution produced after mixing and the secondary phases developed in the tailings material (Fig.2, Table 6). This model revealed that if surface solutions mix with rain water, at any ratio, all secondary phases identified show negative SI values (Table 6), indicating possible dissolution and release of heavy metals to solution.

Table 6 - Calculated Saturation Indices for model "Mixing with Rainwater" for tailings dams T1 and T2 for several Rainwater/Surface water ratios.

\begin{tabular}{|l|c|c|c|c|}
\hline $\begin{array}{l}\text { Mineral } \\
\text { phase }\end{array}$ & $\begin{array}{c}\text { Tailings dump } \\
\text { T1 (1/1 ratio) }\end{array}$ & $\begin{array}{c}\text { Tailings dump } \\
\text { T2 }(1 / 1 \text { ratio })\end{array}$ & $\begin{array}{c}\text { Tailings dump } \\
\text { T1 }(4 / 1 \text { ratio })\end{array}$ & $\begin{array}{c}\text { Tailings dump T2 } \\
\text { (4/1 ratio) }\end{array}$ \\
\hline Anglesite & -0.41 & -0.25 & -0.85 & -0.66 \\
\hline H-jarosite & -5.36 & -1.74 & -6.30 & --2.11 \\
\hline Na-jarosite & -5.89 & -2.60 & -6.85 & -2.99 \\
\hline K-Jarosite & -2.86 & $\mathbf{0 . 2 5}$ & -3.79 & -0.10 \\
\hline Gypsum & -0.96 & -0.91 & -1.47 & -1.38 \\
\hline
\end{tabular}

\subsection{Evaporation}

The third model (Evaporation) examines the evolution of the system and the possible secondary phases resulting from evaporation, at several ratios, of the sampled surface waters and may control the solubility of several toxic metals (Fig.2, Table 7). If the surface waters become more condensed, then the resulting solutions are highly acidic and oxidative with increased metal content. In such conditions precipitation of anglesite, $\mathrm{K}$-jarosite and gypsum is favored, as evident by the positive SI values (Table 7).

Table 7 - Calculated Saturation Indices for model "Evaporation" for tailings dams T1 and $\mathrm{T} 2$ for several evaporation ratios.

\begin{tabular}{|l|c|c|c|c|}
\hline $\begin{array}{l}\text { Mineral } \\
\text { phase }\end{array}$ & $\begin{array}{c}\text { Tailings dump } \\
\text { T1 (x10) }\end{array}$ & $\begin{array}{c}\text { Tailings dump } \\
\text { T2 }(\mathbf{x 1 0})\end{array}$ & $\begin{array}{c}\text { Tailings dump } \\
\mathbf{T 1}(\mathbf{x 4 0})\end{array}$ & $\begin{array}{c}\text { Tailings dump } \\
\text { T2 (x40) }\end{array}$ \\
\hline Anglesite & $\mathbf{0 . 8 9}$ & $\mathbf{1 . 2 4}$ & $\mathbf{1 . 9 6}$ & $\mathbf{3 . 0 4}$ \\
\hline H-jarosite & -1.14 & -2.28 & -0.99 & -2.01 \\
\hline
\end{tabular}


Table 7 continued

\begin{tabular}{|l|c|c|c|c|}
\hline Na-jarosite & -1.35 & -2.94 & -0.86 & -2.15 \\
\hline K-Jarosite & $\mathbf{0 . 3 8}$ & -0.08 & $\mathbf{1 . 9 4}$ & $\mathbf{0 . 3 9}$ \\
\hline Gypsum & $\mathbf{0 . 5 6}$ & $\mathbf{0 . 6 9}$ & $\mathbf{1 . 4 9}$ & $\mathbf{2 . 3 5}$ \\
\hline
\end{tabular}

\section{Conclusions}

The Kirki flotation dams $\mathrm{T} 1$ and $\mathrm{T} 2$ show high $\mathrm{Pb}$ and $\mathrm{Zn}$ content, and lower $\mathrm{Mn}, \mathrm{As}, \mathrm{Cu}$ and $\mathrm{Cd}$ load (Table 2). On site observations revealed that the tailings material is weakly cemented, with alternations of reddish-brown with grayish layers. The secondary phases identified with X-ray Diffraction are only identified in the reddish-brown layers, whereas only gangue and minor gypsum and pyrite are present in the grayish layers. The tailings material is fine-grained with particle size ranging from fine sand to fine silt (Triantafyllidis et al., 2007), thus favoring high rates of reaction between surface waters and tailings solids. Oxidation reactions result in the development of a surface reddish-brown layer prior to the deposition of the next slurry layer in the dams.

The three PHREEQC models employed in this study are focused on the major secondary phases identified in the tailings material of the dams T1 and T2, and in particular jarosite group species, anglesite and gypsum (Table 3 ). The models showed that interaction between surface solutions and tailings material plays a very important role in the fate and transport of certain pollutants.

Jarosite group phases, and in particular K-jarosite, are the major secondary phases identified in the reddish-brown layers of the tailings dams $\mathrm{T} 1$ and $\mathrm{T} 2$. Jarosite is stable in highly acidic and oxidative conditions (especially after significant degree of evaporation - Table 7), and plays a key role in controlling dissolved metal concentration when it precipitates. On the other hand, if the geochemical environment becomes less acidic (e.g. mixing with rain water - Table 6), jarosite is metastable and dissolves (Lottermoser, 2010). Jarosite dissolution after mixing of surface solutions with rainwater favors metal mobility in two ways:

- Direct release of heavy metals and sulfates to solution (e.g. $\mathrm{Pb}^{+2}$ from plumbojarosite in the case of dam T1).

- $\quad$ The dissolved Fe (III) may hydrolyze and precipitate as ferric hydroxide (e.g. goethite). Goethite precipitation causes solution $\mathrm{pH}$ to decrease (production of $\mathrm{H}^{+}$), enhancing heavy metal mobility. Although goethite was not identified by XRD or SEM studies, employed PHREEQC models showed that after mixing with rainwater at any ratio, goethite is supersaturated relative to the developed solution $(\mathrm{SI}>0)$.

Anglesite is also identified in the reddish-brown layers of dams T1 and T2, in lower content relative to jarosite (Table 3). Anglesite may control dissolved concentrations of $\mathrm{Pb}$ more effectively than plumbojarosite (minor secondary phase in tailings dam T1). Anglesite is rather insoluble in the Kirki tailings dams, since it is metastable to cerussite and hydrocerussite only in mildly acidic to alkaline environments with increased $\mathrm{CO}_{2}$ content (Krauskopf and Bird, 1995). No cerussite or hydrocerussite are identified in the tailings material by XRD or SEM, so it is reasonable to assume that such conditions are not developed in the surface environment of the Kirki tailings dams.

Gypsum behaves in a similar manner as anglesite and jarosite. During mixing with rainwater, gypsum is undersaturated relative to the produced solutions, whereas it precipitates when surface solutions become more condensed. Moreover, based on the results of the PHREEQC models applied, hematite and goethite precipitation is favored when conditions turn less acidic, especially after mixing of surface solutions with rainwater, although none of these phases were identified by XRD and SEM in dams T1 and T2.

Finally, it is very important to state that the PHREEQC models applied for the Kirki flotation plant tailings dams T1 and T2 are based on several critical limitations: 
- Systematic sampling is required to focus on the geochemical conditions of the solid-water interface.

- Limited thermodynamic data for other secondary minerals identified in the tailings material.

- Microbial and organic activity within the tailings material. It is known that the role of aerobic bacteria is critical in the initial oxidation/weathering of primary sulfides and sulfosalts (Stokes, 1954; Walsh and Mitchell, 1972; Evangelou, 1983), as well as their catalytic behavior in the formation of secondary phases present in tailings dams.

\section{Acknowledgements}

Part of the research work was funded through the program "IRAKLEITOS - Fellowships for Research of National and Kapodistrian University of Athens - ENVIRONMENT".

\section{References}

Adam, K., 2003. Solid Wastes Management in Sulphide Mines: from Waste Characterisation to Safe Closure of Disposal Sites, Minerals \& Energy, 18(4), 25-35.

Allison, J.D., Brown, D.S. and Novo-Gradac, K.J., 1991. MINTEQA2/PRODEFA2, A geochemical assessment model for environmental systems, Version 3.0 User's Manual, Environmental Research Laboratory, Office of Research and Development, US Environmental Protection Agency, EPA/600/3-91/021, Athens, Georgia, 30605, 92 pp.

Bigham, J.M and Nordstrom, D.K., 2000. Iron and aluminum hydroxysulfates from acid sulfate waters. In: Alpers, C.N., Jambor, J.L. and Nordstrom, D.K., eds., Sulfate minerals. Crystallography, geochemistry and environmental significance, Mineralogical Society of America Reviews in mineralogy and geochemistry, 40, 351-403.

Carroll, D., 1962. Rainwater as a Chemical Agent of Geologic Processes - A Review, U.S. Geological Survey, Washington, Water-Supply Paper 1535-G, 23 pp.

Draves, J.F. and Fox, M.G., 1998. Effects of a mine tailings spill on feeding and metal concentrations in yellow perch (Perca flavescens), Environ. Toxicol. Chem., 17, 1626-1632.

Evangelou, V.P., 1983. Pyritic coal spoils: Their chemistry and water interactions. In: Augustithis, S.S., ed., Leaching and diffusion in rocks and their weathering products, Theophrastus Publications S.A., Athens, Greece, 175-228.

Fergusson, J.E., 1990. The heavy metal elements: chemistry, environmental impact and health effects, Pergamon Press, Oxford, 614 pp.

Groudev, S., Batkova, S.G. and Komnitsas, K., 1999. Treatment of waters polluted with radioactive elements and heavy metals by means of a laboratory passive system, Minerals Engineering, 12(3), 261-270.

Heikkinen, P.M., Räisänen, M.L. and Johnson, R.H., 2009 Geochemical Characterisation of Seepage and Drainage Water Quality from Two Sulphide Mine Tailings Impoundments: Acid Mine Drainage versus Neutral Mine Drainage, Mine Water Environ, 28, 30-49.

Hudson-Edwards, K.A., Macklin, M.G., Jamieson, H.E., Brewer, P.A., Coulthard, T.J., Howard, A.J. and Turner, J.N., 2003. The impact of tailings dam spills and clean-up operations on sediment and water quality in river systems: the Rios Agrio-Guadiamar, Aznalcollar, Spain, Applied Geochemistry, 18, 221-239.

Komnitsas, K., Kontopoulos, A., Lazar, I. and Cambridge, M., 1998. Risk assessment and proposed remedial actions in coastal tailings disposal sites in Romania, Minerals Engineering, 11(12), 1179-1190.

Krauskopf, K.B. and Bird, D.K., 1995. Introduction to geochemistry, McGraw-Hill, New York, USA, $645 \mathrm{pp}$.

Larsen, T.S., Kristensen, J.A., Asmund, G. and Bjerregaard, P., 2001. Lead and zinc in sediments and biota from Maarmorilik, west Greenland: an assessment of the environmental impact of mining wastes on an Arctic fjord system, Environmental Pollution, 114, 275-283. 
Lacal, J., Da Silva, M.P., Garcia, R., Sevilla, M.T., Procopio, J.R. and Hernandez, L., 2003. Study of fractionation and potential mobility of metal sludge from pyrite mining and affected river sediments: changes in mobility over time and use of artificial ageing as a tool in environmental impact assessment, Environmental Pollution, 124(2), 291-305.

Liakopoulos, A., 2009. Environmental study of the former Kirki mines area. Pollution extension and proposed abatement measures, Institute of Geology and Mineral Exploration, Athens, Greece, 257 pp., (in Greek).

Loupasakis, C. and Konstantopoulou, G., 2010. Safety assessment of abandoned tailings ponds: an example from Kirki mines, Greece, Bull. Eng. Geol. Environ., 69, 63-69.

Lottermoser, B.G., 2010. Mine Wastes. Characterization, treatment and environmental impact, Springer-Verlag, Berlin, 400 pp.

Manchester, J.B., Eykholt, G.R., Donohue, S.V. and Cherry, J.C., 2008. Water chemistry and metal cycling in a subaqueous tailings disposal facility. In: Tailings and Mine Waste '08, Taylor \& Francis Group, London, 449 pp.

Michael, K. and Dimadis, E., 2006. Geological study of the area around the Kirki beneficiation plant, Institute of Geology and Mineral Exploration, Athens. Greece, 40 pp., (in Greek).

Moelo, Y., Oudin, E., Makovicky, E., Karup-Moller, S., Pillard, F., Bornuat, M. and Evanghelou, E., 1985. La Kirkiite, Pb10Bi3As3S18, une nouvelle espece minerale homologue de la jordanite, Bull. Mineral., 108, 667-677.

Moelo, Y., Makovicky, E., Karup-Moller, S., Cervelle, B. and Maurel, C., 1990. La levyclaudite, $\mathrm{Pb} 8 \mathrm{Sn} 7 \mathrm{Cu} 3(\mathrm{Bi}, \mathrm{Sb}) 3 \mathrm{~S} 28$, une nouvelle espece a structure incommensurable, de la serie de la cylindrite, Eur. J. Mineral., 2, 711-723.

Mohamed, A.M.O., Hossein, M. and Hassani, F.P., 2002. Hydro-mechanical evaluation of stabilized mine tailings, Environmental Geology, 41, 749-759.

Parkhurst, D.L. and Appelo, C.A.J., 1999. User's guide to PHREEQC (version 2) - a computer program for speciation, batch-reaction, one-dimensional transport and inverse geochemical calculations, U.S. Geological Survey, Denver, Colorado, report 99-4259.

Plumlee, G.S. and Logsdon, M.J., 1999. An earth system science toolkit for environmentally friendly mineral resource development. In: Plumlee, G.S. and Logsdon, M.J., eds., The Environmental Geochemistry of Mineral Deposits. Part A: Processes, Techniques, and Health Issues, Society of Economic Geologists, Reviews in Economic Geology, 6A, 1-27.

Skarpelis, N., 1999. The Agios Filippos ore deposit, Kirki (Western Thrace). A base metal part of a high sulfidation epithermal system, Bull. Geol. Soc. Greece, XXXIII, 51-60.

Stokes, J.L., 1954. Studies in the filamentous iron bacterium Sphaerotilus natans, Journal of Bacteriology, 67, 278-291.

Triantafyllidis, S., 2006. Environmental risk assessment of mining and processing activities and rehabilitation proposals in Evros and Rhodope Prerefectures (Thrace, NE Greece), Unpublished Doctoral Thesis (in Greek), Faculty of Geology and Geoenvironment, University of Athens, Athens, Greece, $378 \mathrm{pp}$.

Triantafyllidis, S., Skarpelis, N. and Komnitsas K., 2007. Environmental characterization and geochemistry of Kirki, Thrace, NE Greece, abandoned flotation tailings dumps, Environ Forensic, 8(4), 351-359.

Walsh, F. and Mitchell, R., 1972. A pH-dependent succession of iron bacteria, Environmental Science and Technology, 6, 809-812.

Wray, D.S., 1998. The impact of unconfined mine tailings and anthropogenic pollution on a semiarid environment - an initial study of the Rodalquilar mining district, southeast Spain, Environmental Geochemistry and Health, 20, 29-38. 